\title{
A Strategy for the Promotion of Health Literacy in Portugal, Centered around the Life-Course Approach: The Importance of Digital Tools
}

\author{
Andreia Silva Costa ${ }^{a}$ Miguel Arriaga $^{b}$ Rita Veloso Mendes ${ }^{c}$ Débora Miranda \\ Patrícia Barbosa ${ }^{e}$ Constantino Sakellarides ${ }^{f}$ André Peralta ${ }^{g}$ \\ Nuno Ambrósio Lopes ${ }^{h} \quad$ Célia Roque $^{i}$ Sofia Ribeiro $^{j}$

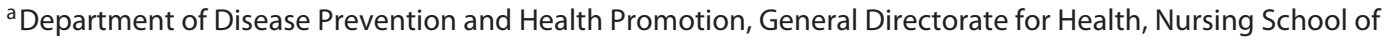
General Directorate for Health, Health Policy Implementation, Higher School of Sports RM, Lisbon, Portugal; 'Centro de Investigação e Estudos de Sociologia, ISCTE-IUL, Public Health Research Center, Escola Nacional de Saúde Pública, Universidade NOVA de Lisboa, Lisbon, Portugal; ${ }^{d}$ Health Communications Consultant, Lisbon,

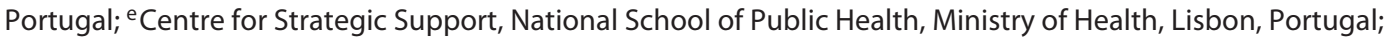
${ }^{f}$ National School of Public Health, Lisbon, Portugal; ${ }^{9}$ Public Health Research Center, Escola Nacional de Saúde


Health, Regional Health Administration of Lisbon and Tagus Valley, Lisbon, Portugal; 'Department of Patients' Management, Hospital Center of Setúbal, Setúbal, Portugal; 'ISAMB Environmental Health Institute, University of
\end{abstract} \\ Lisbon, ISAMB Environmental Health Institute, University of Lisbon, Lisbon, Portugal; ${ }^{\mathrm{b}}$ Division of Healthy Lifestyles, \\ Lisbon, Lisbon, Portugal
}

\section{Keywords}

Health literacy · Information technology · Preventative programs

\begin{abstract}
Applied to health, literacy enhances the capacity to make the decisions that are necessary for autonomous health management. With this position paper, we intend to defend the thesis that the conditions for creating a national strategy for health literacy in Portugal along the life course are strengthened by the modernization of the National Health Service (SNS). First, we conducted a scope review on health literacy, and then we collected data on the National Strategy for Health Literacy and the different actions around it. The Literacy Program in Health and Care Integration, aligned with the modernization program of the National Health Service "SNS + Proximidade," has been developed based on a
\end{abstract}

\section{KARGER}

E-Mail karger@karger.com www.karger.com/pjp

Karger Open access (c) 2019 The Author(s). Published by S. Karger AG, Basel on behalf of NOVA National School of Public Health

This article is licensed under the Creative Commons AttributionNonCommercial-NoDerivatives 4.0 International License (CC BYNC-ND) (http://www.karger.com/Services/OpenAccessLicense) Usage and distribution for commercial purposes as well as any distribution of modified material requires written permission. life course approach. On the other hand, the National Strategy for Health Literacy, in addition to encompassing different dimensions of health literacy, from the individual and community level to the health systems, also presents strategic opportunities for intervention in contexts associated with different determinants of health. The digital Health Literacy Library of the SNS Portal is the first tool to integrate this strategy, being a digital repository of resources to support the promotion of health literacy, accessible at all times. These resources include interactive digital health books and the "My Health Journal," encouraging people to organize their health information and take control of their health throughout their lives. The strategy also includes plans to bring these resources to people in various everyday contexts, such as public libraries, schools, and day centers, enabling their activation. At the same time, the digital modernization of the SNS allows health information to be made available in the Citizen Area of the SNS Portal, for example,
Andreia Silva Costa

Alameda Dom Afonso Henriques PT-1000-123 Lisbon (Portugal)

E-Mail andreiasilva @dgs.min-saude.pt 
by facilitating each citizen's access to their health information in a confidential way. The entire process of implementing the health literacy strategy is dynamic and aims to encourage all citizens to participate in its construction and evaluation, and consequently in its adaptation and continuous improvement.

(c) 2019 The Author(s) Published by S. Karger AG, Basel on behalf of NOVA National School of Public Health

\section{Uma estratégia para a promoção da literacia em saúde, centrada nos percursos de vida: a importância das ferramentas digitais}

\section{Palavras Chave}

Literacia em saúde · Tecnologias de informação ·

Programas preventivos

\section{Resumo}

Aplicada à saúde, a literacia aumenta a capacidade dos cidadãos tomarem decisões para uma gestão autónoma da saúde. Com este position paper, pretende-se defender a tese de que se encontram reunidas as condições para criar, em Portugal, uma estratégia nacional para a literacia em saúde ao longo do percurso de vida, fortalecida pelo contacto com a modernização do Serviço Nacional de Saúde (SNS). Em primeiro lugar, foi conduzida uma revisão sobre literacia em saúde, e em seguida foram recolhidos dados sobre a Estratégia Nacional para a Literacia em Saúde e sobre as diferentes ações relacionadas com a mesma. O Programa de Literacia em Saúde e Integração de Cuidados, alinhado com o programa de modernização do Serviço Nacional de Saúde "SNS+ Proximidade," tem vindo a ser desenvolvido em função de uma abordagem ao longo do percurso de vida. Por outro lado, a Estratégia Nacional para a Literacia em Saúde, para além de englobar diferentes dimensões da literacia em saúde, desde o nível individual e comunitário até aos sistemas de saúde, apresenta também oportunidades estratégicas de intervenção em contextos associados aos diferentes determinantes da saúde. A Biblioteca de Literacia em Saúde do Portal SNS é a primeira ferramenta que integra esta estratégia, sendo um repositório digital de recursos de apoio à promoção da literacia em saúde, acessíveis em permanência. Estes recursos incluem livros digitais interativos sobre saúde e o "Diário da Minha Saúde," incentivando as pessoas a organizar a sua informação sobre saúde e a assumir o controlo da sua saúde ao longo da vida. A estratégia inclui ainda planos para levar estes recursos às pessoas em vários contextos quotidianos, como bibliotecas, escolas e centros de dia, permitindo a sua ativação. Paralelamente, a modernização digital do SNS permite a disponibilização de informação sobre saúde na Área do Cidadão, por exemplo, facilitando o acesso de cada cidadão à sua informação sobre saúde de forma confidencial. Todo o processo de implementação da estratégia de literacia em saúde é dinâmico e pretende incentivar todos os cidadãos a participar na sua construção e avaliação e, consequentemente, na sua adaptação e melhoria contínua.

(c) 2019 The Author(s). Published by S. Karger AG, Basel on behalf of NOVA National School of Public Health

\section{Introduction}

Literacy, which can be defined as the ability to use the skills taught and learned, is a determinant of individual and collective behaviors, as well as of participation in society. When applied to health, literacy enhances the capacity to make the necessary decisions for an autonomous health management [1-4]. Health literacy can also be extended to communities, while considering social and cultural contexts. Here, the concept of critical health literacy emerges. This concept considers the overall picture and thus enables people to make decisions about their individual health and the health of their community [5]. In the societal context we live in nowadays, acquiring competencies in the field of health literacy implies individual challenges, such as managing the volume of information available and confronting the need for a healthy lifestyle. Therefore, committing to actions that provide all people with access to important and good quality information contributes to increasing essential skills such as critical thinking to face decisions that affect the health of each person throughout their life. If, in the life course, the emergence of new technologies implies growing health decisions, the exponential growth of forms and channels of communication fosters the concept of multiliteracy, which is the use of multiple channels of communication, to multiple audiences, in the dissemination of multiple health contents. In addition, the capacity and motivation of people to access and understand health information is diverse; therefore, this information should be available in different formats and through different channels [6].

When applying the methodology developed by Sorensen [2012] in 2014, 11\% of the Portuguese population had an "inadequate" level of health literacy, $38 \%$ had a "problematic" level, $41 \%$ had a "sufficient" level, and 9\% had an "excellent" level [6]. In 2016, another study con- 
ducted in Portugal indicated that $61 \%$ of the reporting population had an ill-health or inadequate level of health literacy [7]. However, the population is increasingly educated, and its health literacy levels are very close to the European average [7-9].

In this opinion article, we aim to present our opinion on how the introduction of digital tools can contribute to the improvement of health literacy in the Portuguese population.

The Literacy Program in Health and Integrated Care of the XXI Constitutional Government, initially designated as the National Program of Education for Health, Literacy and Self-Care, since integrated in the modernization program of the National Health Service entitled "SNS + Proximidade," has been developed through a life-course approach. To fully integrate people's health management, "SNS + Proximidade" emerges as a transversal driver of the different National Health Programs. In this context, instruments for the promotion of health literacy have been developed, also based on the valorization of the life course, aiming at better communication, information, and activation.

The National Strategy for Health Literacy integrates resources used that can be divided into two main lines: the promotion of good, evidence-based professional practice and the investment in promoting people's health literacy, both through smart and opportunistic use of technical and technological innovation. In this opinion article, we present three tools, which were created under the project.

\section{Digital Reference Repository “Health Literacy Library"}

The Health Literacy Library of the SNS Portal aims to be a digital repository of reference for the consultation of information and resources that represent good practices in promoting health literacy, available to citizens and health professionals. It allows citizens, patients, caregivers, and other professionals to search for and access validated information on a specific topic, autonomously or accompanied. The repository highlights resources related to the importance of an active life and health promotion, to the detriment of specific diseases. The Library is an electronic platform that results from the continuous selection, aggregation, validation, and dissemination of existing resources to support the promotion of health literacy. This information can be consulted by topic or by stage of the life cycle - from birth through to the end of life. The Library has an editorial group who validate and guarantee the reliability of the sources of the information available by analyzing the technical file of each resource, including its scientific evidence base, periodic updating of its contents, and addressing improvement recommendations to authors. The Library also includes guidelines for the production and application of resources to promote health literacy to stimulate an intelligent network of individuals and institutions dedicated to sharing good practices at a national level.

\section{Multiliteracy through Digital Books}

Many of the existing resources eligible for integration into the Library are of high technical quality but limited communicational quality. According to the health literacy strategy presented, they need to be improved in terms of graphics and content to have an impact on their target audience. To invest in the communicability of some resources and themes, and to promote good literacy practices, "SNS + Proximidade" included the development of a collection of digital books on health cross-cutting issues such as prevention of falls, food, healthy relationships, winter care, social isolation, and navigation in the NHS. In the production of each book, technical and editorial teams are involved to ensure that the information is credible and presented in an appealing way to its target audience, being accessible through channels such as the SNS Portal, among others.

\section{Empowering the Receiver: My Health Journal}

In addition to providing information and improving its communicability, it is also necessary to equip receivers with instruments that allow them to organize and personalize this information. The "Diário da Minha Saúde" (My Health Journal), available at the SNS Portal and its Citizen Area, is an instrument for citizen empowerment with a view to their activation. It allows people to add information about their life path that is relevant to their health, in a personalized and confidential digital space. Contents may include excerpts from readings, multimedia content, narratives about personal experiences, timing and preparation of queries, among other information and content of interest. In this context, narrative medicine is of particular relevance, including its therapeutic relevance. Scientific evidence has shown that people who write about their traumatic experiences reveal significant improvements in
Port J Public Health 2019;37:50-54 DOI: $10.1159 / 000500247$
Silva Costa et al. 
various aspects of health and decrease the number of visits to the doctor [10]. In addition, giving people "control of their health information is increasingly recognized as an important step in improving health quality" [11].

In addition, narrative is important to understand the meaning of a disease from a patient's perspective - not only a pathological description, but a description of living with pathology. As such, it promotes mutual understanding (health professional-patient and caregiver) and helps contextualize medicine and disease on a cultural, social, and historical level, in line with the concept of critical literacy.

\section{Activation Processes}

Nowadays, we see the transition from an approach through which health professionals provide information to change the patient's behavior to an approach that recognizes the value of the person acquiring self-management skills. Health professionals should help patients gain control over their health by recognizing and understanding their role and the importance of communicating and collaborating with them [12].

In fact, improving the quality and controlling the costs of health services increasingly requires the active participation of informed consumers through the effective use of information. The lack of patient engagement contributes significantly to preventable deaths. However, this patient engagement is not measured by the number of logins, uploads, or downloads of information but by the real interaction and participation of people in the management of their health $[13,14]$.

The last step of the health literacy strategy is, therefore, to promote the activation of people, which means moving literacy into action. Activation represents a person's knowledge, technical ability, confidence, and motivation to self-manage their health and/or illness [11]. It is therefore intended that people use these or other literacy promotion tools and benefit from them, increasing their confidence and ability to manage their own health.

This activation may occur, for example, through engaging in debates and pedagogic activities of leisure, change of health behaviors, or greater collaboration with health professionals. The strategy includes the planning and implementation of activation exercises, both in health services, such as health-care centers, as well as in public spaces, such as libraries. The goal is to encourage different audiences to reflect on and debate health-related themes, testing literacy tools in real-life situations, and assessing the extent to which their access, understanding, and uti-

Health Literacy Strategy in Portugal lization contribute to a better individual health management.

Through the use of metrics such as the Patient Activation Measure, it is possible to measure activation levels resulting from specific activities, segment populations, and align strategies according to their activation levels [6, $12,15,16]$.

\section{Evaluation and Future Steps}

Developing and evaluating such platforms is challenging insofar as different types of interventions lead to different human behaviors. It is crucial to analyze the duration of interventions, their health outcomes, and the type and usability of the technology used, including whether it is simple and intuitive to use, is available where its users are, and responds to their real needs $[14,17]$.

The evaluation of all activities to promote activation within the scope of the National Strategy for Health Literacy is essential. It is urgent to promote research and evaluation of strategies and characteristics of interventions that use new information technologies to personalize information and promote behavior change. It may have a direct impact in several areas such as health promotion, reduction of risk behaviors, control of chronic illness or undue access to emergency services, and bet on projects that lead to an increase in levels of health literacy. Activation can have an impact on indirect gains related to the reduction of costs associated with the provision of care or with increasing productivity.

Thinking about the process of increasing the capacity to access, understand, interpret, and use information about health on the one hand, and to change behaviors on the other, is a critical success factor across all measures of action and projects to be developed, the success of each action being proportional to the capacity and competencies of each individual to improve the management of their health throughout life. It is important to realize that there is a distinction between the direct and indirect effects of health literacy on health behaviors, health status, and some disease behaviors. Conceptually, health literacy can be understood as a specific social determinant of health, as a mediator of the impact of other social determinants of health, or as a moderator in such behavioral processes.

This is a clear space for public health intervention in Portugal. The National Strategy for Health Literacy intends to represent this space, with concrete strategic axes to promote literacy and health throughout its spectrum. 


\section{References}

1 Institute of Medicine. Health and Medicine Division. Health literacy: a prescription to end confusion. [Internet] Washington, DC: National Academy of Sciences; 2004 [cited 2018 May 11]. Available from: http://www. nationalacademies.org/hmd/Reports/2004/ Health-Literacy-A-Prescription-to-EndConfusion.aspx.

2 Sykes S, Wills J, Rowlands G, Popple K. Understanding critical health literacy: a concept analysis. BMC Public Health [Internet]. 2013 [cited 2018 May 11];13:150. Available from: http://bmcpublichealth.biomedcentral.com/ articles/10.1186/1471-2458-13-150.

3 Berwick D, Kickbusch I, Bos W, Lobo J, Pedro A, Barros P, et al. Um futuro para a saúde: todos temos um papel a desempenhar [Internet] Lisboa: Fundação Calouste Gulbenkian; 2014. [cited 2018 May 15]. Available from https:// content.gulbenkian.pt/wp-content/uploads/2016/03/30003651/PGIS_BrochuraSumarioFUTUREHealthPortugues. pdf.

4 de Wit L, Fenenga C, Giammarchi C, di Furia L, Hutter I, de Winter A, et al. Communitybased initiatives improving critical health literacy: a systematic review and meta-synthesis of qualitative evidence. BMC Public Health [Internet]. 2018 [cited 2018 May 11];18(1):40. Available from: http://bmcpublichealth. biomedcentral.com/articles/10.1186/s12889017-4570-7 https://doi.org/10.1186/s12889017-4570-7.

5 Chinn D. Critical health literacy: a review and critical analysis. Soc Sci Med. 2011 Jul;73(1): 60-7.
6 Marrin K, Rix A. Prudent health care and patient activation: an appraisal prepared for the Planned Care Programme. Cardiff: Welsh Government; 2016.

7 Pedro AR, Amaral O, Escoval A. Literacia em saúde, dos dados à ação: tradução, validação e aplicação do European Health Literacy Survey em Portugal. Rev Port Saúde Pública. [Internet]. 2016 [cited 2018 May 11];34(3):25975. Available from: http://www.scielo.mec. pt/pdf/rpsp/v34n3/v34n3a08.pdf https://doi. org/10.1016/j.rpsp.2016.07.002.

8 Sørensen K, Van den Broucke S, Fullam J, Doyle G, Pelikan J, Slonska Z, et al. Health literacy and public health: a systematic review and integration of definitions and models. BMC Public Health [Internet]. 2012 [cited 2018 May 11];12(1):80. Available from: http:// bmcpublichealth.biomedcentral.com/articles/10.1186/1471-2458-12-80 https://doi.org /10.1186/1471-2458-12-80.

9 Ávila P, Espanha R. ILS-PT: Inquérito à Literacia em Saúde Portugal. [Internet]. Lisboa: Fundação Calouste Gulbenkian. CIES. IUL; 2015. [cited 2018 May 15]. Available from: https://www.academia.edu/21502281/ILS_PT_ Inquérito_à_Literacia_em_Saúde_Portugal.

10 Stuckey HL, Nobel J. The connection between art, healing, and public health: a review of current literature. Am J Public Health. 2010 Feb; 100(2):254-63.

11 Laranjo L. Cuidados de saúde centrados na pessoa e tecnologias de informação e comunicação: perspetivas atuais e futuras. Rev Port Med Geral e Fam. [Internet]. 2015 [cited 2018 May 15];31(6):372-4. Available from: http:// www.rpmgf.pt/ojs/index.php/rpmgf/article/ view/11621 https://doi.org/10.32385/rpmgf. v31i6.11621.

12 Hibbard J, Gilburt H. Supporting people to manage their health: an introduction to patient activation. London: Kings Fund; 2014.

13 Jones SS, Caloyeras J, Mattke S. Power to the people: the role of consumer-controlled personal health management systems in the evolution of employer-based health care benefits. Santa Monica (CA): RAND Corporation; 2011.

14 Sawesi S, Rashrash M, Phalakornkule K, Carpenter JS, Jones JF. The impact of information technology on patient engagement and health behavior change: a systematic review of the literature. JMIR Med Inform. 2016 Jan; 4(1):e1.

15 Hibbard JH, Stockard J, Mahoney ER, Tusler M. Development of the Patient Activation Measure (PAM): conceptualizing and measuring activation in patients and consumers. Health Serv Res. 2004 Aug;39(4 Pt 1):1005-26.

16 Nijman J, Hendriks M, Brabers A, de Jong J, Rademakers J. Patient activation and health literacy as predictors of health information use in a general sample of Dutch health care consumers. J Health Commun. 2014;19(8): 955-69.

17 Ringlein L. Using health IT for patient engagement, consumer activation. [Internet]. Danvers, MA: PatientEnagagementHIT. Xtelligent Media; 2016. [cited 2018 May 15]. Available from: https://patientengagementhit.com/news/using-health-it-for-patientengagement-consumer-activation. 